\title{
The Nuclear Issue in the South Pacific: \\ Labor Parties, Trade Union Movements, and Pacific Island Churches in \\ International Relations
}

Jean-Marc Regnault

Since the end of World War II, various negotiations, with or without the immediate agreement of the two "superpowers" of the time, the United States and the Soviet Union, have been undertaken in order to prevent a military nuclear presence or even the use of civil nuclear power in some parts of the world (the nuclear-weapon-free zones) - or indeed in space. Following treaties relating to the Antarctic (1959) and Latin America (Tlatelolco Treaty, 1967), the Treaty of Rarotonga (Cook Islands), signed on 6 August I985, seeks to make the South Pacific nuclear free. More recent treaties concern Southeast Asia and Africa (Szurek 1997). In addition, some cities, such as Faa'a, on Tahiti, have proclaimed themselves "nuclear free" without this status having any legal value.

France has generally shown reticence with regard to such treaties. ${ }^{1}$ This was the case with the Treaty of Rarotonga before France decided to sign it in I996. In the South Pacific, France has been the focus of opposition from states, trade unions, and churches because it needed to use the South Pacific, which the Anglo-Saxon powers readily consider their backyard. However, France was not the only country to be targeted. From the early I970s, under the leadership of New Zealand, the Pacific Island countries embarked on what they considered a new crusade, which was to lead to the signing of the Treaty of Rarotonga.

\section{The Cold War and Nuclear Testing in the Pacific}

Through the I95I Australia-New Zealand-United States (ANZUS) security pact for the Pacific and the 1954 Southeast Asian Treaty Organiza-

The Contemporary Pacific, Volume 17, Number 2, 339-357

(C) 2005 by University of Hawai'i Press 
tion (seato), Australia and New Zealand took up a position in the confrontation between the power blocs, even though the nuclear threat did not, in principle, affect them directly. Under these treaties, US warships did not have to declare the nature of the weapons they carried. The governments did not initially react. But when the pacifist movement gathered strength in the early I980s, Australia and especially New Zealand had to find an appropriate response, as nuclear testing was now taking place in their region, where the bombing of Hiroshima and Nagasaki had already disconcerted Pacific Island communities.

From I945 to 1963, the United States carried out 232 atmospheric nuclear tests. Those that took place in the Pacific occurred on Bikini Atoll (42 explosions) and on Enewetak (60), both in the (now) Republic of the Marshall Islands; on Johnston Island (II) in the Northeast Pacific; and on Christmas (Kiritimati) Island (I3), an atoll that is part of the present Republic of Kiribati. The power of the explosion above Enewetak on I November 1952 left the island severely damaged.

The United Kingdom carried out its first atmospheric tests from 1952 on Montebello Island off Western Australia, in the Indian Ocean (3), and on two supposedly deserted sites in South Australia, Emu Field and Maralinga (Iо), with the approval of the Australian authorities, until 1957. Ten other tests, thermonuclear in nature, took place on Malden and Christmas Islands in the (then) British colony of the Gilbert Islands.

Some of the atmospheric testing was not carried out under optimum safety conditions. The July 1946 atomic explosions on Bikini greatly exceeded the forecast maximum radioactivity level. The communities of the Micronesian islands of the US Trust Territories were displaced without being able to return permanently to their ancestral homeland. With the support of various protest movements, they took legal action against Washington for compensation for the high cancer rates affecting them. On I March 1954, the first thermonuclear bomb, Bravo, exploded over Bikini (I7 megatons rather than the announced 5). Forty-eight hours later, the US Navy evacuated hundreds of people from Rongerik, Rongelap, and Utirik. A Japanese fishing boat, the Fukuryu Maru, found itself in the fallout zone and its twenty-three crew members were seriously contaminated. Henceforth, the US military conducted its testing in the greatest secrecy.

At Montebello in Australia, little concern was shown for local communities (some 5,000 people, mostly Aborigines). The testing carried out at Maralinga and Emu Field caused the death of Aboriginal nomadic huntergatherer groups who had been neither alerted nor removed from the test- 
ing zones. The British tried to clean up the area without much success. The Federal Australian Radiation Laboratory maintains that tens of thousands of pieces of plutonium-contaminated debris are still there, making any human presence impossible. ${ }^{2}$ From 1957 to 1963 , the British pursued their atmospheric testing in the greatest secrecy in the Northeast Pacific, for example, at Christmas Island.

Because it had never colonized the region nor conducted nuclear testing in the South Pacific, the Soviet Union's nuclear capability was not an issue in the region.

As the destructive capacity was becoming terrifying, in 1959, the three nuclear powers (United States, United Kingdom, and Soviet Union) decided to establish a moratorium on nuclear testing, before realizing the need to sign a test ban treaty. The first anti-nuclear movements could consider that part of their goal had been achieved, but before signing the Moscow Treaty (5 August 1963), the three powers accelerated the rate and power of their tests. ${ }^{3}$ This being so, nuclear initiatives by France and China, who were beginning testing in the early I960s, could only be very badly perceived, particularly in the Pacific.

When France had to abandon its testing ranges in the Sahara Desert, it chose the South Pacific atolls of Moruroa and Fangataufa in French Polynesia as alternative sites (Regnault 2000) (see map I). Testing began on I July 1966. On 24 August 1968, the first thermonuclear test took place on Fangataufa. In the Pacific, France carried out 4I atmospheric tests (I966-I974) and I40 underground tests (I975-I99I and I995-I996).

Reaction by the people of French Polynesia may have taken quite a long time to emerge, but other Pacific territories and states swiftly expressed opposition.

\section{Rising Opposition to French Testing, BUT ALSO TO US HEGEMONY}

Vigorous reactions met the announcement of the commissioning of the Pacific Testing Center (Centre d'Experimentation du Pacifique, or CEP). The French government complained about the "systematic campaign conducted in New Zealand against its testing plans." ${ }^{4}$ A union leader in New Zealand stated that de Gaulle had "a ridiculous attitude on the issue of nuclear weapons." 5 New Zealand's Conservative prime minister declared his country's "aversion to nuclear testing." 6 At the United Nations, New Zealand claimed to be the only country "to have stressed the hazards of 


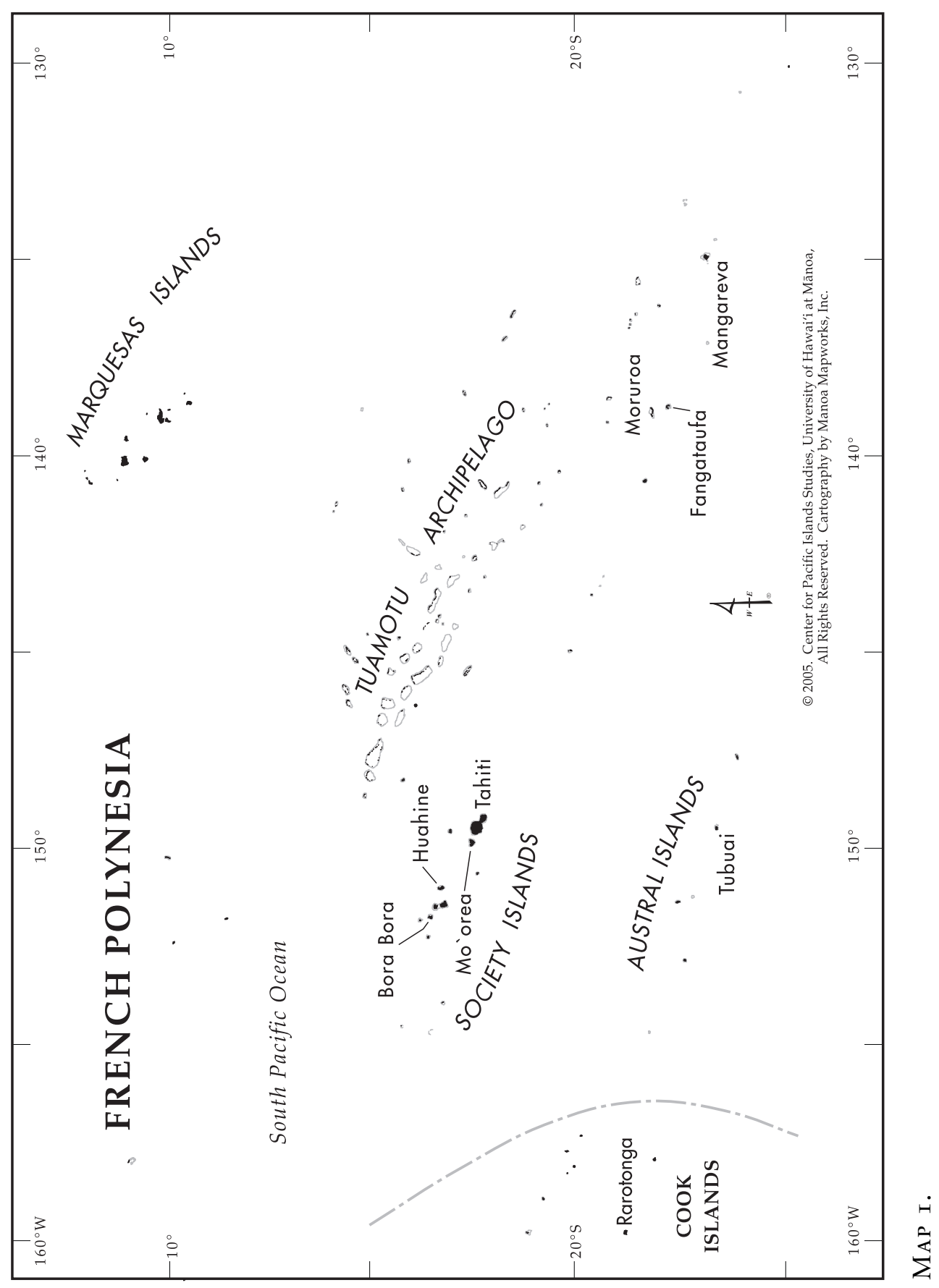


nuclear testing in the Pacific." 7 The Labour Party opposition supported the idea of a boycott of French goods, "even if the New Zealand economy had to suffer," and also proposed the establishment of nuclear-free zones and the banning of nuclear weapons,${ }^{8}$ which the Conservative government rejected.

The New Zealand unions were joined by their Australian counterparts: "The Australian Foreign Affairs Minister, Mr Hasluck, declared on 4th November 1964 to his French counterpart, Couve de Murville, that he was resigned to continued testing but feared proliferation and fallout and therefore desired consultation" (Vaïsse I998, 377).

This agitation elicited a virulent response from General de Gaulle, who did not understand how French policy in this area could be attacked, because "our bomb is a peaceful one and it is the most peaceful thing we've invented since France came into existence"; for the general, New Zealand protests could only come from "old spinsters' societies" (Peyrefitte I997, I20-I24). But he clearly understood the thinking in the region, which he had visited in 1956. His comments also referred to Tahiti's history, the Pritchard Affair in particular. ${ }^{9}$ De Gaulle observed that neither Australia nor New Zealand had protested to Washington, London, or Moscow about their testing (Vaïsse I998, 377). He was not really surprised to learn that "the Tahitian pastors meet English and American pastors who raise anti-French sentiment in them and Pacific Island pastors with whom they get mutually agitated," but the extension of such opposition did not bother him greatly. What was important for him was "that the construction of our nuclear force is a very important matter for France and the construction of the Pacific Testing Center is a great French project" (Peyrefitte 1997, I20-I24). And it is precisely around that issue that opposition to France in the Pacific developed or was resuscitated. The Pacific Island countries applied logic that must be understood: "The countries of the region consider that this nuclear testing, far from indirectly protecting them against a threat to the Western world in the context of the Cold War . . . would force them into the spiral of terror in the event of nuclear conflict" (Cordonnier I995, 2I).

For these countries, the atomic weapon is not considered a deterrent but an instrument of total destruction. Themes uniting pre-Christian or Christian religious myths and ecology were revived: God gave the Pacific Islanders their land pure and untouched. The French were polluting the atmosphere and the entrails of the earth on those two atolls. This was against God's will because he wanted to see the purity of these islands 
maintained. 10 "If the testing is not dangerous, then why not choose a site in mainland France?" was a frequently asked question.

New Zealand was France's ally and friend. General de Gaulle confided to New Zealand Prime Minister Holyoake, "France will not forget the bonds of friendship that it has with New Zealand, especially since the two world wars" (Vaïsse I998, 203). But France had disappointed New Zealand. From the early I970s (and in particular between 1972 and I975, when Labour was in power), New Zealand embarked on a series of measures in order to

- have French nuclear testing outlawed by the United Nations;

- lay the matter before the International Court of Justice (as the court had ordered the halt after France had stopped atmospheric testing, it considered the complaint lodged by Australia and New Zealand no longer valid); and

- plan to set up a nuclear-free zone.

Although more moderate, Australia supported its neighbor's approach. The action taken was negatively perceived by the United States, because Australia and New Zealand seemed to be aligning themselves with the communist and Third World countries on this issue.

During the same period, in Wellington in $197 \mathrm{I}$, the first meeting was held of the member countries of the South Pacific Forum, this being an institution within which independent countries could address their development priorities. ${ }^{11}$ Australia and New Zealand were not supposed to become members, but the need to find funding for the organization required their inclusion. ${ }^{12}$

The Forum rapidly became an active diplomatic instrument against France. It bitterly challenged nuclear testing in French Polynesia and "colonialism" in New Caledonia. It consistently criticized the "arrogant" attitude of France. Wellington and Canberra led a hostile campaign against France. Outside the Forum, other countries were also concerned about French testing. The Chilean Senate denounced "a threat for neighboring countries," while Peru threatened to break off its diplomatic relations with France. ${ }^{13}$

In French Polynesia itself, anti-nuclear activism developed under pressure from local autonomists and French and foreign pacifists. ${ }^{14}$ However, France was not the only country in their sights. The United States was increasingly perceived as indirectly threatening regional peace and secu- 
rity. New Zealand was often in the vanguard of this combat, without really jeopardizing the ties between the Anglo-Saxon powers.

In Fiji, in I970, a religious anti-nuclear movement was born: АТОM (Against Tests On Moruroa). ${ }^{15}$ Its members belonged to the Protestant Pacific Theological College in Suva, the University of the South Pacific, and the Fiji Young Men's Christian Association (YMCA). Quickly securing the support of the Pacific Conference of Churches, ${ }^{16}$ АTOM organized the first Nuclear-free Pacific Conference in I975. On I I December 1975, the UN General Assembly considered a resolution on this topic, jointly signed by New Zealand, Papua New Guinea, and Fiji, and adopted it by i Io votes to $\circ$ with 20 abstentions, including the United States and the Soviet Union.

Атом broadened its base by including trade unions, nongovernmental organizations, women's movements, religious groups, and a range of disarmament lobbies. Атом's arguments were as follows: If all Islands enjoyed constitutional independence, the colonial powers would be forced to do their testing elsewhere. It was therefore necessary for all Island groups to achieve independence.

The South Pacific countries saluted the victory of François Mitterrand in I98I, but they had not measured the changes in the French socialist movement at the end of the I970s. The new president considered that "to give up any of the current defense resources at all" would be equivalent to giving up French independence (quoted in Fisher 1982, 79).

The 1983 Nuclear Free and Independent Pacific Conference held in Port Vila planned the introduction of a nuclear-free zone including, in addition to the South Pacific, Micronesia, the Philippines, Japan, and Hawai'i. All nuclear weapons would be banned, including those onboard ships. The conference also demanded independence for the Kanaks, a halt to the Indonesian transmigration policy in Irian Jaya, ${ }^{17}$ the closure of US military bases in the Philippines, a ban on the dumping of nuclear waste in the Pacific Ocean, and a halt to the use of Kwajalein Atoll as a target for MX missiles. The positions taken at this conference were "maximalist." 18

In August 1984, the Forum decided to draft a treaty to make the Pacific Islands region a nuclear-free zone. This task was entrusted to a working group and to the lawyers of the Foreign Affairs Ministry of Australia, which had taken a moderate position. Australian Prime Minister Bob Hawke intended to maintained freedom of movement in international waters and the sovereignty of each regional state in terms of transit authorizations through national waters or visits to regional ports. ${ }^{19}$ 
The parties agreed to meet the following year in Rarotonga, Cook Islands, to sign the desired treaty.

I984-I995: The Misfortunes OF

The Rarotonga Treaty

The treaty ran into troubled waters during its preparation and in its implementation.

The working group adopted the following principles: no use, no testing, and no stationing of explosive nuclear devices in the Pacific. The plan was to propose them as binding protocols to the five nuclear powers (now including France and China). But in terms of international law, how could such a ban be adopted without discrediting the treaty from the outset?

What would be the name of the future nuclear-free zone: "Pacific"? But that was too general. "South Pacific" was too restrictive, although it did stress the regional identity. "Nuclear-free zone" was preferred to "nuclearweapon-free zone," as this terminology made it possible to include the dumping of radioactive waste at sea as well (Japan was referred to here).

But despite the consensus commitment to achieving this goal, there remained major differences between the Forum states. Australia, who played the main role in the process, led the moderate camp. Fiji attached itself to this group, after giving up its extreme positions, because it needed financial support from the United States.

In the "maximalist" camp stood Walter Lini (an Anglican priest, prime minister of Vanuatu from I980 to I99I; an Anglophone, he had often expressed his opposition to the French position in the Pacific) and especially his New Zealand counterpart, David Lange. The Labour Party's I984 victory was Lange's own; his program focused on the environment, pacifism, and the need to ban nuclear activities. For Lange, a strict Protestant, notions of general disarmament and world peace went hand in hand with the moral obligation to oppose any use of nuclear energy. He had another strongly worded draft prepared, reflecting the frame of mind of New Zealand, which, in order to step onto the international stage, intended to become the representative for pacifist and ecologist utopias.

The signing of the treaty was scheduled for 6 August 1985 during the Forum summit in Rarotonga. Some sixty journalists attended and prepared various reports on "the French colonial presence" in New Caledonia and the oppression of the Kanaks, French nuclear testing, and some historical material on US and British nuclear accidents in the region, 
among other topics. Further spice was added the same week by the revelation that the supposed Swiss newlyweds, "Alain and Sophie Turenge" responsible for the sabotage of the Rainbow Warrior, which was sunk on Io July that year in Auckland Harbour, were in fact two French army officers. The Pacific Islanders were shocked because they considered this as an "act of state terrorism."

Delegations from all Forum member countries and nongovernmental organizations such as Greenpeace attended the summit, as did Kanak independence movement representatives and Gaston Flosse, president of French Polynesia.

Despite his positions, David Lange was appointed to chair the summit. Bob Hawke used the independence issue in New Caledonia, which he supported, to gain the support of other Forum members on the minimalist nuclear-free-zone treaty project and also reconquer his labor electorate, who were disappointed by his domestic policies. The Melanesian states considered the "Australian" draft too timid and also wanted to express unconditional support for the Kanak cause.

The anti-nuclear lobby believed that the priority was the treaty, not the status of New Caledonia. Other considerations disrupted the serenity of the summit: Kiribati, for example, wanted to enter into a financial agreement with the Soviet Union in the fisheries area, as it could no longer wait for the United States to deliver on its promises.

After the necessary compromises, the final communique referred to selfdetermination in New Caledonia and its inscription on the list of the UN Special Committee of 24 on Decolonization. ${ }^{20}$ Reference was made to trade, political, and development cooperation, as well as support for the Federated States of Micronesia and Palau, which were undergoing US pressure over nuclear issues. French nuclear testing and nuclear waste dumping in the ocean were deplored.

The treaty itself includes a very general preamble on "a world at peace" and the concern to "keep the region free of environmental pollution by radioactive wastes"; sixteen articles; and four annexes defining the geographical boundaries of the zone and specifying arrangements to monitor implementation of the three protocols intended for the major powers. It goes further than the Nuclear Non-Proliferation Treaty [first signed on I July 1968 by sixty-two countries] by banning nuclear arms and devices from the territories of the parties, under whoever's control they may be, and by banning the "stationing of any nuclear explosive device" (Article $5)$, but the transit of ships is not explicitly banned. Article 5 leaves it up 
to each state to refuse or to allow visits by ships that could carry such nuclear devices.

The treaty was first signed and then gradually ratified over time by ten countries: Australia, Cook Islands, Fiji, Kiribati, New Zealand, Niue, Solomon Islands, Tuvalu, Papua New Guinea, and Western Samoa. Two countries categorically refused to sign the treaty for different reasons: Vanuatu (because the treaty did not ban visits by ships) and Tonga (which had never been anti-nuclear). Vanuatu finally signed it in September I995 and ratified it, since new Prime Minister Maxime Carlot was more moderate than his predecessor. [Tonga signed the treaty in 2000.]

Bob Hawke was given a bad time by the press, who considered his attitude hypocritical, since Australia sold uranium to France. Concerning the ban on the stationing of nuclear-powered vessels, David Lange wondered what distinction Australia made between transit and prolonged calls at ports, since US nuclear submarines called at Fremantle, Western Australia.

On the New Zealand side, the press welcomed this treaty even if its value was symbolic. The prime minister stated that France would again give an arrogant image of itself if it did not sign at least two of the three protocols. France was not the only country that came in for criticism. Australians and New Zealanders stressed the fact that the treaty should strengthen the Non-Proliferation Treaty and encourage other countries to go down the same road: the treaty was just one step toward worldwide peace and security.

For the treaty to have value, it would have to be approved by the major powers. All were favorable, in principle, to the emergence of nuclearweapon-free zones, but the United Kingdom, France, and China wished to reduce the gap in size between the arsenals of the two superpowers on the one hand and theirs on the other. France raised three extra conditions:

- nuclear disarmament should go together with a total ban on testing;

- there should be a correction of major imbalances in terms of chemical and conventional weaponry; and

- no new system, particularly defensive, should imperil the current foundations of deterrence and, therefore, peace.

After becoming prime minister in 1986, Jacques Chirac introduced a Secretariat of State for South Pacific affairs. He appointed Polynesian Gaston Flosse to head this office. ${ }^{21}$ Flosse's task was to renew dialogue with the region and justify French positions. His action mainly focused on the Poly- 
nesian triangle and Fiji. He invited various leading political figures from the area to Moruroa and developed an image of France somewhat different from that to which the media had accustomed the people of the area. A South Pacific assistance and cooperation fund was placed at his disposal. However, France confirmed its hostility to the treaty's first protocol, which it considered "prejudicial to Western interests." 22

The United Kingdom had to contend with the fact that the modernization and testing of its nuclear weapons, as well as their possible conditions of use, were dependent on the United States, and that much of the UK political spectrum (Labour and Liberal parties) was opposed to the concept of nuclear deterrence. London's evasive position inconvenienced Paris, since Moscow was stepping up its attempts to interfere in the South Pacific area. ${ }^{23}$

The increasingly hostile attitude of New Zealand, which in 1987 banned from its ports vessels containing nuclear explosives or operating with nuclear power, irritated the United States, which decided to expel this country from the ANzus pact. In response to New Zealand and Soviet agitation, on 5 February 1987, Washington announced its official refusal to sign the protocols. The United Kingdom followed suit on 20 March of the same year.

The day after the summit, the TASs news agency on behalf of the Soviet Union congratulated the Forum countries for adopting the treaty despite pressure from the United States, France, and the United Kingdom. The Soviet Union signed the second and third protocols (as the first protocol only concerned states with territories in this area) on I 5 December 1986. Because the treaty advocated a certain amount of independence from the two superpowers, China ratified it on 2I October 1988.

The Rarotonga treaty was particularly designed to oppose French nuclear testing. President François Mitterrand did try to improve France's image in the Pacific, ${ }^{24}$ but without much real success. From I99I on, he changed French policy by announcing his wish to sign the Nuclear NonProliferation Treatry. For domestic and foreign policy reasons, in April I992 he decided to suspend testing for one year. He said that France wanted to call a halt to over-arming and the build-up of nuclear weapons in the world. This earned France the congratulations of the South Pacific countries. ${ }^{25}$ This unilateral moratorium did not in any way mean that he was giving up the principle of nuclear deterrence, which remained the cornerstone of French defense policy. US President George Bush, initially reluctant, agreed to a nine-month moratorium. In 1993 France extended 
its moratorium indefinitely, and US President Bill Clinton announced a fifteen-month moratorium and an intention to draft a multilateral Comprehensive Test Ban Treaty.

On I3 June 1995, the new French president, Jacques Chirac, announced a final nuclear testing program in French Polynesia, citing technical considerations and the need to maintain his country's deterrent. Domestic policy considerations also explained his decision; he who claimed to be de Gaulle's successor had to make deterrence a priority. At the same time, Chirac expressed France's determination to sign the Comprehensive Test Ban Treaty, once it was ready, and the Treaty of Rarotonga.

While protests grew ever more vocal in South Pacific countries, supported by the World Council of Churches, ${ }^{26}$ and Fiji suggested that France should withdraw its ambassador, peaceful marches mobilized thousands of people in Tahiti in June and July 1995, prompted by the independence movements and the Evangelical Church.

On 5 September 1995 , the first of the six nuclear devices of the final program was exploded. The next day, violent rioting broke out in the capital Papeete, filmed by journalists from all over the world, attracted by the prospects of a spectacular confrontation between the army and Greenpeace, which had promised that five boats would be sent to the territorial waters of French Polynesia. The rioting left twenty hurt, four of them seriously. Damage was estimated at millions of Pacific francs. Relayed by television channels, images of extreme violence threw a deep shadow over French Polynesia's image in the outside world, where tourism was one of the country's vital resources. More than I0,000 demonstrators gathered in the capital the following Saturday to criticize, first of all, the attitude of the French State, which had not wanted to take action to prevent the rioting taking place, as well as the use of violence by some independence movement and trade union leaders.

The five remaining French nuclear tests took place with no reaction in the territory. Each test was announced to wide regional and international disapproval. The last test took place on 27 January 1996.

\section{From i996 to the Present: Back to the Happy Isles?}

On 20 October 1995 , France, the United Kingdom, and the United States announced their intention to sign the three protocols. Ten years after the Rarotonga Summit, the nuclear-free South Pacific was on the verge of becoming a reality. In the meantime, the world had changed and the 
Pacific Islands had certainly lost some of their importance to the great powers. Why should they refuse to sign the treaty any longer?

On 29 January 1996, President Chirac announced the final halting of French nuclear testing. He gave Gaston Flosse authority to sign the three protocols in Suva on 25 March I996. The ceremony took place in the presence of the US and UK ambassadors, who were cosignatories with Gaston Flosse on behalf of their respective countries.

As it had done with the Treaty of Tlatelolco, in signing this treaty France expressed reservations and made interpretative statements, such as: "No provision of the protocols or articles of the Treaty to which they refer may harm the full exercise of the natural right to self-defense provided for by Article 5I of the United Nations Charter."

After the signing, South Pacific Forum Chair Julius Chan, prime minister of Papua New Guinea, stated that he would have preferred a more complete agreement relating to the exporting of uranium and the presence and transit of nuclear-powered vessels; he also expressed the wish that monitoring of the environment be continued as regards all results of nuclear activity and that financial compensation be offered if necessary.

Flosse stressed that no nuclear testing area had been as closely studied as Moruroa from the environmental point of view. The expert mission requested of the International Atomic Energy Agency (IAEA) would publish its results on the nonhazardous nature of the tests. ${ }^{27}$

With the Antarctic, Tlatelolco, Rarotonga, Bangkok, and Pelindaba treaties, the whole of the southern hemisphere had begun to become a nuclear-weapon-free zone. The Comprehensive Test Ban Treaty was signed in I996; the Non-Proliferation Treaty was considered at the New York Conference in April and May 2000. Would the world at last be rid of the threat of nuclear apocalypse and the Pacific Islands again become the "Happy Isles"? (Coutau-Bégarie 1987, 265).

Not only is it not as simple as that, ${ }^{28}$ but also nobody can hope to construct a haven of peace in isolation from the rest of the planet. For the South Pacific, since the final adoption of the Rarotonga Treaty, the situation is fairly disparate, with some problems being happily resolved and new threats now occurring.

One very positive aspect is the warming (albeit still somewhat fragile) of the relationship between France and the South Pacific countries. For example, in Paris, at the end of October 1997, Jim Bolger, the New Zealand prime minister, stated that his country had forgiven France for the Rainbow Warrior affair. 
France wanted to project the image of a friendly and altruistic power, while the United Kingdom had withdrawn in 1996 from the regional institutions, ${ }^{29}$ the United States was closing its embassies in the South Pacific and considerably reducing its aid, ${ }^{30}$ and Australia was also apparently disengaging. John Howard stated at the end of August 200I: "The Pacific has to find its own solutions. Australia cannot and has no intention of determining the course of events in the region ... Independence also means taking charge of one's own destiny." 31

France therefore maintained the South Pacific assistance fund set up by Jacques Chirac, responsibility for which former President Mitterrand had given to a diplomat (acting as permanent secretary for the South Pacific) attached to the prime minister's office. In recent years, this fund has been worth some I 5 million French francs annually.

However, the challenging of France is not over. The battle continues around the theme of how safe testing really was. The Nuclear Arms Observatory (Observatoire des armes nucléaires françaises, or OBSARM) set up in 1984 has published highly critical reviews on the health of former Moruroa workers, and, despite the somewhat reassuring IAEA report, they are worried about the possible future contamination of the ocean. ${ }^{32}$ This action is echoed in the territory by the Evangelical Church, and in the Pacific by the Protestant churches, but also, more discreetly, by the Catholics. As time passes, the Evangelical Church's position becomes tougher. The Protestants find it hard to accept the secrecy policy used by France. A gesture of repentance, but also financial compensation, is being demanded of France.

Paradoxically, the French presence in the Pacific has found new justification since recent developments. Many problems are now arising. There is a worrying situation in Fiji (multiple coups), in Papua New Guinea and Solomon Islands (ethnic tensions), and in Vanuatu (political instability). Faced with extensive immigration from many Island countries, Australia and New Zealand are much less hostile now to the French presence in the Pacific and only provide moderate support to independence movements.

An alarming picture of the Pacific Islands can be drawn. There is a real risk of seeing most of the Pacific Island entities become the neglected victims of globalization. Some states, principally the corrupt elites, are allowing themselves to be manipulated to launder dirty money. ${ }^{33}$ Suspect networks, linked with the drug trade or fraudulent banking operations, are operating in the region.

The disruption of climate patterns has become a major concern, mainly for the atoll archipelagoes. The 200I Forum expressed its concern and 
asked the United States to review its position on the Kyoto Protocol. According to the preamble to the Rarotonga Treaty, the states of the South Pacific are "determined to ensure that the bounty and beauty of the land and sea in their region should remain the heritage of their peoples and their descendants in perpetuity." It is no longer the nuclear threat that concerns them but the rise in the level of the ocean waters and the violence of the cyclones.

THIS ESSAY IS A SHORTENED VERSION of an article published in French in 2003 in the Revue d'Histoire Diplomatique, which cordially grants permission for this publication.

\section{Notes}

I In June 1988, Roland Dumas, then minister of Foreign Affairs, stated that France was favorable to Nuclear Weapon Free Zones, provided that "such a commitment stems from the unanimous will of all the states concerned and that it can be satisfactorily monitored" (quoted in Maurice and Gohin I99I, 477).

2 Under public pressure, in 1984 the Labour government set up a Royal Commission of Inquiry into British testing in Australia. The results were published in The Report of the Royal Commission into British Nuclear Tests in Australia, Canberra: Australian Government Publishing Service, I985.

3 The United States tested on Christmas Island, which was a source of concern to the people of French Polynesia (in the Marquesas in particular) and Western Sāmoa.

4 French Ministry of Foreign Affairs, letter from the French ambassador in Wellington, dated 4 October 1963.

5 Le Monde, 2 February 1963.

6 Letter from the French ambassador dated 22 November 1963.

7 Letter dated 4 October 1963.

8 Opposition to France was also sustained by unfounded rumors and false images: The Australian and New Zealand media illustrated reports on French testing with pictures from Bikini and Enewetak. A photographic montage showed an atomic mushroom cloud above Tahiti (Pacific Island Trade News [Sydney], I7 July 1972).

9 In I842, the Reverend Pritchard, who hoped that Tahiti would become a British protectorate, was moved aside by a maneuver in favor of France. This affair led to a serious misunderstanding between the Protestant countries of the region and France (De Deckker 1997).

ıo The Evangelical Church of French Polynesia, which took up an anti- 
nuclear stance in 1982, believed that "nuclear testing has been and will remain for all time the greatest crime ever committed against the Fenua" (the Fenua being the land and country of French Polynesia) (Vea Porotetani [Papeete monthly], October 2000).

I I The largest of the regional organizations, the South Pacific Commission was established in 1947 (becoming the Pacific Community in 1998) at the initiative of the colonial powers with territories in the region. Its charter precluded any political debate. As independence arrived in the Pacific, the new countries set up the South Pacific Forum, an institution existing alongside the commission.

I 2 The Pacific peoples believed that, in order to belong to the region, they had to have been there since before the arrival of the Europeans. On occasion they have claimed first occupants' rights. The way they viewed New Zealand and Australian leaders could therefore have been totally negative. But religious criteria, history, and the political skill of these larger countries rallied the people of the South Pacific behind them, especially against France.

I3 Le Monde, I 5-I6 July 1973.

I4 In 1972, Greenpeace attempted to hinder testing by sailing close to Moruroa. In 1973, well-known French figures came to support the anti-nuclear activists. Some New Zealanders joined the movement with the frigate Otago. Their prime minister declared: "We are not here to interfere in what the French are doing, but to witness illegal acts" (Le Monde, I6 July 1973).

I 5 For Protestant German theologian Helmut Gollwitzer, this weapon possesses particular features: "severe or irreversible damage (during testing also) to God's creation (nature and humankind) and possible destruction of the whole planet. Any use of this weapon must therefore be opposed, as must its use as part of a deterrence policy, as well as any research in this field" (Encylopédie du Protestantisme [Paris: Éditions du Cerf; Geneva: Éditions Labor et Fides] I995, I, 6I 8-6I9). This vision was also the subject of a solemn statement by the World Council of Churches in 1983. In 1955, Pope Pius XII stated his opposition to nuclear testing. The 1963 papal encyclical Pacem in Terris proposed disarmament and the banning of nuclear weapons. Soon, Protestants and Catholics, in different ways, would simultaneously assert their opposition to testing.

I 6 The Pacific Conference of Churches was set up in 1966 by the Protestants, and the Pacific Conference of Bishops joined in 1976. The Pacific Conference of Churches was a very active organization against residual forms of colonialism and the nuclear threat.

I7 Jakarta claimed Dutch New Guinea as an integral part of Indonesia and made it into an Indonesian province (Irian Jaya) in 1963.

I 8 For example, this statement from the conference report, published by the Pacific Concerns Resource Center: "our environment continues to be despoiled by foreign powers" (II).

I9 The Australian and New Zealand Labour parties, after adopting anti- 
nuclear stances, won power on 5 March I983 and I4 July I984, respectively. During military maneuvers, a British aircraft carrier sustained damage and requested permission to call at Sydney arsenal for repairs. Canberra declined. After US Secretary of State George Schultz intervened, authorization was finally given.

20 At the United Nations, on 2 December 1986, the resolution to reinscribe New Caledonia on the list of non-self-governing territories was passed, with 89 votes for, 24 against, and 34 abstentions.

2I Gaston Flosse was born in I93I. Once a primary school teacher, he went into business and then politics. He became the leader of Tahoera'a Huiraatira (Rally of the People). He adopted the goal of French Polynesia's self-government in 1978 , and has dominated politics there since 1982 , serving first as vice president (I982-I984), and as president from I984 to I987 and since I99I.

22 Le Monde, I7 December 1986. Ivan Barko has analyzed the difficult relations between France and Australia while Jacques Chirac was prime minister (2003).

23 Vanuatu had established ties to Libya and Cuba.

24 Efforts included scientific missions (Haroun Tazieff, Jacques Cousteau, New Zealand scientist H R Atkinson); a diplomatic mission by Régis Debray; an invitation to Tahitian pastors to visit Moruroa; a roundtable meeting in Papeete (October 1989) on the health and economic impacts of nuclear testing; and establishment of the French University of the Pacific.

25 However, the Forum leaders remained cautious, fearing a resumption of testing and its long-term consequences (Le Monde, 22 June 1994).

26 In August 1985, the World Council of Churches issued a booklet, In the Name of life ... No! (and a French version, Au nom du Dieu de vie . . Non!), which was very critical of the resumption of testing.

27 The International Atomic Energy Agency (IAEA), a UN agency with headquarters in Vienna, was established in October 1956 for the purpose of promoting the peaceful use of atomic energy and controlling nuclear activities to avoid their use for military purposes. The agency was involved in the verification of compliance with the rules laid down in the Nuclear Non-Proliteration Treaty and the treaties instituting the nuclear-weapon-free zones.

28 Readers may recall the Indian and Pakistani testing in May 1998, the US refusal to ratify the Comprehensive Test Ban Treaty, George W Bush's anti-missile shield, and, more generally, all other threats posed by current weaponry.

29 The following year, the United Kingdom decided to reenter the Pacific Community, using the pretext that it possessed Pitcairn, the former refuge of the Bounty mutineers. This enables the United Kingdom to attend conferences of the organization, while providing a contribution of only 0.007 percent of its budget. [Britain has since withdrawn again from the Pacific Community.]

30 Le Monde, 6 September 1996.

3I La Dépêche de Tahiti [Papeete weekly], 24 August 200I. Australia's sup- 
port for the Regional Assistance Mission to Solomon Islands (RAMSI) shows that their attitude has changed radically. [See Tarcisius Tara Kabutaulaka's article, "Australian Foreign Policy and the RAmsi Intervention in Solomon Islands," this issue, 283-309.]

32 The Radiological Situation on the Atolls of Moruroa and Fangatanfa. IAEA report, published in December 1998. "For many Polynesians and Melanesians who live off the sea, to imagine poisoned fish and reef destruction is intolerable. No matter how many reports are published demonstrating the absence of any leaks or pollution, they will not shake the certainties widely shared by the South Pacific peoples. Cold reasoning and Cartesian logic have no hold over emotional positions. The peoples of the Pacific perceive nuclear testing as violation and sacrilege" (Le Monde, 22 June 1994).

33 The Organisation for Economic Co-operation and Development has threatened the states of Nauru, Niue, Vanuatu, and Cook Islands with sanctions after 30 September $200 \mathrm{I}$ if their tax legislation is not changed, which for the moment is not fully the case.

\section{References}

Barko, Ivan

2003 L'Australie face a la politique française dans le Pacifique de I98I a 1988. In François Mitterrand et les territoires français du Pacifique (198I-1988): Mutations, drames et recompositions; Enjeux internationaux et franco-français, edited by Jean-Marc Regnault, 507-5I7. Paris: Les Indes savantes.

Cordonnier, Isabelle

I995 La France dans le Pacifique Sud: Approche géostratégique. Paris: Publisud.

Coutau-Bégarie, Hervé

I987 Géostratégie du Pacifique. Paris: Economica.

Crocombe, Ron

I995 The Pacific Islands and the USA. Suva: Institute of Pacific Studies, University of the South Pacific; Honolulu: Pacific Islands Development Program, East-West Center.

De Deckker, Paul

I997 Jacques-Antoine Moerenhout (I797-1879): Ethnologue et consul. Papeete: Au Vent des îles.

Denoon, Donald, Philippa Mein-Smith, with Marivic Wyndham 2000 A History of Australia, New Zealand, and the Pacific. Oxford: Blackwell Publishers.

Duval, Marcel, and Yves Le Baut

1992 L'Arme nucléaire française: Pourquoi et comment? Paris: SPM. 
Fisher, Georges

I982 La France et le désarmement. Annuaire Français de Droit International 28:79-I 26.

Howe, K R, Robert C Kiste, and Brij V Lal

I994 Tides of History: The Pacific Islands in the Twentieth Century. Sydney: Allen \& Unwin; Honolulu: University of Hawai'i Press.

Maurice, Pierre, and Olivier Gohin

I99I Géopolitique et géostratégie dans l'Hémisphere Sud. Université de la Réunion.

Peyrefitte, Alain

I997 C'était de Gaulle. Vol 2: La France reprend sa place dans le monde. Paris: Éditions de Fallois, Fayard.

Regnault, Jean-Marc

2000 La France à la recherche de sites nucléaires; I957-I963. Cahiers $d u$ Centre d'Études d'Histoire de la Défense I2:29-54. English translation published as: France's Search for Nuclear Test Sites, I957-I963. The Journal of Military History 67 (Oct 2003): I223-I 248.

Szurek, Sandra

I997 De Rarotonga à Bangkok et Pelindaba. Note sur les traités constitutifs de nouvelles zones exemptes d'armes nucléaires. Annuaire Français de Droit International, I996, I64-186. Paris: Centre national de la recherche scientifique.

Tubanavau-Salabula, Losena, Josua M Namoce, and Nic Maclellan

1999 Kirisimasi: Fijian Troops at Britain's Christmas Island Nuclear Tests. Suva: Pacific Concerns Resource Center.

Vaïsse, Maurice

I998 La Grandeur: Politique étrangère du Général de Gaulle. Paris: Fayard. 